\title{
Manipulation of Original Ideology Through Translation: A Discourse-Based Translation Quality Assessment of Speeches
}

\author{
Majid Khorsand (Corresponding Author) \\ Department of English, East Azarbaijan Science and Research Branch, Islamic Azad University, Tabriz, Iran \\ E-mail: khorsand.majid@gmail.com \\ Bahloul Salmani \\ Department of English, East Azarbaijan Science and Research Branch, Islamic Azad University, Tabriz, Iran \\ E-mail: salmanibb@yahoo.com
}

Received: 06-03-2014

Accepted: 11-05-2014

Published: 01-09-2014

doi:10.7575/aiac.ijalel.v.3n.5p.134

URL: http://dx.doi.org/10.7575/aiac.ijalel.v.3n.5p.134

\begin{abstract}
The main focus of this paper is on speeches in literary discourse as the superb ideological displays of propaganda as well as their translations for having an enormous capacity for ideological manipulation. In this paper, the only present English-Azarbaijani Turkish translation of Squealer's speech from Orwell's Animal Farm was discoursally analyzed based on House's revised translation quality assessment (TQA) model. According to this model, speeches as propaganda in literary texts must be translated overtly to meet the standards of an adequate translation. Of the main criteria of an overt translation are co-activating the original discourse world and being equivalent at the levels of text, register, and genre. With respect to covertly and overtly erroneous errors, the findings of the study demonstrated that enormous ideological distortions and manipulation were carried out in the Turkish translation. Therefore, the translation was a covert and inadequate one. Moreover, the social effect the source and target texts' readerships receive would be radically different from each other. Finally, some implications and suggestions for further studies were proposed.
\end{abstract}

Keywords: Ideology, Manipulation, Squealer's speech, Discourse analysis, House's revisited TQA model

\section{Introduction}

It can be claimed that every text or its translation is conditioned and inscribed within a given discourse and ideology. Discourse Analysis is the deconstructive reading and interpretation of a text to disclose the concealed stimuli behind the text and discover its ideological manipulation in the translation. Literary translation can be distinguished from other types of translation because of its particular ideological discourse. Speeches within this discourse are sometimes presented by professional (deceitful) propagandists. Speeches in literary texts are formal talks and (in some cases) replete with false and deceptive facts called propaganda. Propaganda is a specific type of message demonstration intended to set an agenda and serve a power agency. Propaganda refers to "ideas or statements that are often false or exaggerated and that are spread in order to help a cause, a political leader, a government, etc." (Merriam-Webster, 2014). The purpose of propaganda is to serve an agenda by a specific type of message demonstration. Thus, speeches in literary discourse are the superb ideological displays of propaganda (see Khorsand \& Salmani, 2014). A literary translation should reflect the imaginative, intellectual and intuitive writing of the author. Belhaag (1997, p. 20) summarizes the characteristics of literary translations as "expressive, connotative, symbolic, focusing on both form and content, subjective, allowing multiple interpretation, timeless and universal, using special devices to heighten communicative effect, [and having a] tendency to deviate from the language norms" (as cited in Hassan, 2011, pp. 2-3). Smiley (2005, p. 24) discusses that "the most important essential characteristic of the novel that arises out of its structure, out of the combination of narrative and length, is that it is inherently political." Furthermore, speeches in literary texts are fundamentally political and one of the most challenging and demanding areas in translation studies (TS). On the other hand, speeches as propaganda in a novel like Animal Farm makes the context more political. The significance of discourse analysis of speeches as propaganda lies behind discovering their embedded message(s). If that hidden message is disclosed, it will expand our horizons towards the author's perspectives and ideologies. This discovery assists the reader to comprehend the situation and respond based on his or her realization and capacity. But to what extent is a translator allowed to do this job? What criteria give this permission to the translator? Should the translator leave the message hidden in the text? To what extent does the translator afford the target text's readership the same opportunity in the target culture (TC) that the source text's readership experiences in the original culture? To what extent is it possible for the translator to co-activate the original discourse world in spite of the sociocultural linguistic differences between the source and target languages? The main concern of this paper is the discoursal quality assessment of the only present English-Azarbaijani Turkish translation of Squealer's speech from Orwell's Animal Farm. The assessment was based on House's $(1997,2009)$ revised TQA model. The qualitative method of the research is discussed in details in the third section of this paper, corpus and method. The expressions Azarbaijani Turkish and 
Azerbaijani Turkish [emphasis added], in this paper, refer to the languages spoken and written in northwestern Iran and Azerbaijan respectively. However, the sociolinguistic differentiation between English and Turkish makes this study both complicated and intriguing in its unique case. This study aimed to efficiently answer the questions as follows: (a) What ideological distortions and manipulation were carried out in the Turkish translation of Squealer's speech? (b) What covertly and overtly erroneous errors were found through the comprehensive discoursal quality assessment of the Turkish translation of Squealer's speech? (c) To what extent could the Turkish translators afford to co-activate the original discourse world? (d) To what extent is there a match between the functions of the source and target languages?

\section{Literature Review}

\subsection{Ideology and Propaganda}

Ideology has been defined by many scholars depending on their perspectives. Ideology refers to (a) a systematic body of concepts especially about human life or culture, (b) a manner or the content of thinking characteristic of an individual, group, or culture, and (c) the integrated assertions, theories and aims that constitute a sociopolitical program (MerriamWebster, 2014). Mayr (2008, pp. 10-11) categorizes the scholars' definitions of ideology as two major perspectives: “a relativist definition, denoting systems of ideas, beliefs and practices, and a critical definition, allied with Marxist theory, which sees it as working in the interests of a social class and/or cultural group". It can be claimed that every original text and its translation have ideologies to transmit to their readerships. The original ideologies might be manipulated through the process of translation. Hence, there is a special relationship between ideology and translation and in the case of this study between Squealer's speech in Animal Farm and its English-Turkish translation.

Propaganda is the systematic distribution of information and ideologies, "especially of a biased or misleading nature, used to promote a political cause or point of view" (OUP, 2014). In other words, propaganda is "the spreading of ideas, information, or rumor for the purpose of helping or injuring an institution, a cause, or a person" and it refers to the "manipulation of information to influence public opinion" (Merriam-Webster, 2014). The aim of propaganda is to convince people to accept certain beliefs or facts undoubtedly. On the other hand, by demonstrating only one side of an argument, it is a type of communication intended towards influencing the attitude of the community in tune with some cause or position. Propaganda, in simple words, refers to intentionally untrue or deceptive information that back up a political cause or the benefits of those in authority. By contrast, a message does not need to be false to qualify as propaganda. Regarding the repetition and dispersion over the worldwide media, propaganda aims at creating certain effect and outcome in audience attitudes. Moreover, lexical choices in the use of propaganda play a significant role in its sociopolitical function and discourse. A propagandist pursues to alter the approach people comprehend an issue or situation in order to manipulate their actions and expectations in accordance with a power or an agent's interest. The power or agent might have political, sociological, economic, and/or psychological tendencies and intentions. Squealer's speech occurs within the fable of Animal Farm and it is presented by the minister of propaganda as one of the prominent politicians of the fable. This proves that the speech is truly political. Concerning Squealer's job in favor of Napoleon, Chilton and Schäffner (1997, p. 212) argue that if a text or an action takes account of power or resistance, it is apt to be political. Gagnon (2010, p. 252) underlines that "when studying political translations two different objects of study are to be considered: translation of political texts and translation as a political statement. In both cases, the meaning of the adjective 'political' is central to the analysis". However, "propaganda in Animal Farm is used to deceive, mystify and bewilder the animals, to conceal the reality of the situation, [to evade any factual and conceptual issues] and to stop them thinking for themselves" (Khorsand \& Salmani, 2014, p. 225). The expression "to think for yourself" means "to form your own opinions and make decisions without depending on others" (OUP, 2014). It is obvious that thinking for yourself [emphasis added] necessitates fulfilling some essential requirements in order to stay away from being someone else's puppet. Some of them are claimed to include asking questions, looking for reasons, challenging yourself, speaking up (i.e. expressing your opinion clearly, openly, freely and confidently), not being afraid of disagreeing (i.e. not involving in blind conformity), doing the research into the others' statements, questioning your own assumptions and being bold, and being cautious about paralysis by analysis (i.e. there will always be some degree of uncertainty).

\subsection{Squealer and His Ideological Tactics and Approaches}

Authored by Orwell, Animal Farm is an allegorical, sociopolitical, ideological and anti-totalitarian fable, and an antiutopian satire. Ending in a victory for the animals, the novel begins with a war. With regard to the novel and according to Gradesaver:

Animal Farm was published on the heels of World War II, in England in 1945 and in the United States in 1946. George Orwell wrote the book during the war as a cautionary fable in order to expose the seriousness of the dangers posed by Stalinism and totalitarian government. . . . The tragically violent events of the war set the stage well for Orwell's fictional manifesto against totalitarianism. (Retrieved 22/7/2013)

As the symbol of a totalitarian government's propaganda minister, Squealer is the most dominant and influential propagandist of the novel and his Speech is one of the most outstanding samples of propaganda in Orwell's Animal Farm. The novel begins with a war leading to a victory. Since maintaining the spirits and morale of the country was important, Squealer's job was to persuade all animals to follow the revolution. Squealer's name was among the most frequent names repeated in the novel. After Napoleon (168), Snowball (131), Boxer (96), and Jones (83), his name appeared 67 times in the novel. This indicates his significant role among many characters in the novel.

There have been many tactics that Squealer applied to his speech and statements through the novel. Moreover, he 
applied several clever approaches in dealing with the animals and the pigs, i.e. the public and the elite respectively. Squealer's appearance, personality, perspectives, ideology and interaction with the animals and the pigs were summarized in the following. The first six items (2.2.1-6) refer to some of the techniques and strategies that are usually applied to propaganda illuminated by Khorsand and Salmani (2014, p. 224). It should be underlined that the real examples were included from the novel under each category.

2.2.1 Selected facts in support and confirmation of an idea or statement:

On Sunday mornings Squealer, ... would read out to them lists of figures proving that the production of every class of foodstuff had increased by two hundred per cent, three hundred per cent, or five hundred per cent, as the case might be. The animals saw no reason to disbelieve him, especially as they could no longer remember very clearly what conditions had been like before the Rebellion. (Orwell, 1945, p. 47)

2.2.2 Lying and purposefully deceiving through an intentionally untruthful statement:

A too rigid equality in rations, Squealer explained, would have been contrary to the principles of Animalism. . . . (Squealer always spoke of it as a "readjustment," never as a "reduction"), but in comparison with the days of Jones, the improvement was enormous. Reading out the figures in a shrill, rapid voice, he proved to them in detail that they had more oats, more hay, more turnips than they had had in Jones's day, that they worked shorter hours, that their drinking water was of better quality, that they lived longer, that a larger proportion of their young ones survived infancy, and that they had more straw in their stalls and suffered less from fleas. The animals believed every word of it. (p. 53)

2.2.3 Repetition, that is, retelling the same words repeatedly to be imprinted on the people's mind forever:

"Forward, comrades!" he whispered. "Forward in the name of the Rebellion. Long live Animal Farm! Long live Comrade Napoleon! Napoleon is always right." (p. 59)

2.2.4 Identifying the (true or false) enemy, that is, diverting the public opinion and attention into an imaginary enemy away from the speaker:

One false step, and our enemies would be upon us. Surely, comrades, you do not want Jones back? (pp. 33-34)

... Snowball was Jones's agent from the very beginning-yes, . . "I warn every animal on this farm to keep his eyes very wide open. For we have reason to think that some of Snowball's secret agents are lurking among us at this moment!" (p. 43)

2.2.5. Rhetorical questions (are intended not to encourage a specific answer, but rather to elicit an audience to regard a message or perspective):

Do you know what would happen if we pigs failed in our duty? Jones would come back! Yes, Jones would come back! (p. 26)

..., but Squealer asked them shrewdly, "Are you certain that this is not something that you have dreamed, comrades? Have you any record of such a resolution? Is it written down anywhere?" And since it was certainly true that nothing of the kind existed in writing, the animals were satisfied that they had been mistaken (p. 37).

2.2.6 Contention, that is, bold statements:

The whole management and organization of this farm depend on us. Day and night we are watching over your welfare. (p. 26)

Napoleon had never in reality been opposed to the windmill. On the contrary, it was he who had advocated it in the beginning, ... (p. 34)

Squealer told them that the pigs had to expend enormous labors every day upon mysterious things called "files," "reports," "minutes," and "memoranda." (p. 61)

2.2.7 Manipulation and abuse of language (SparkNotes, 2007):

(a) Fundamentally simplifying language in order to limit the terms of debate:

"Four legs good, two legs better!" (Orwell, 1945, p. 63)

(b) Complicating language unnecessarily to confuse and intimidate the uneducated:

We pigs are brainworkers. ... (p. 26)

(c) Employing jargon (i.e. the language which is difficult for other people to understand) to engender in the other animals both self-doubt and a sense of hopelessness about ever accessing the truth without the pigs' mediation:

Tactics, comrades, tactics! (p. 34)

2.2.8 Being a deceitful gentleman. In appearance, he is associated with a fat rich roughneck man. Like an experienced businessman, he could convince the animals and make them believe in his statements:

The best known among . . [ [porkers] was a small fat pig named Squealer, with very round cheeks, twinkling eyes, nimble movements, and a shrill voice. He was a brilliant talker, and when he was arguing some difficult point he had a way of skipping from side to side and whisking his tail which was somehow very persuasive. The others said of Squealer that he could turn black into white. (p. 18)

2.2.9 Diplomatic interaction. Squealer is the most prominent stereotype of a professional propagandist. He knows what 
to do, when to act, how to behave, when and where and how what to say. Even any change in his posture and facial expression is not arbitrary but meticulously and deceitfully planned and purposeful. Thus he is the main responsible pig for transmitting the pigs' ideology to the animals. Furthermore, Squealer can easily make pretense at seriousness, being in tears, feeling sympathy for the animals, and so forth:

Squealer was sent to make the necessary explanations to the others. (p. 25)

Here Squealer looked very sly. (p. 34)

... he cast a very ugly look at Boxer with his little twinkling eyes. (p. 43)

In his speeches, Squealer would talk with the tears rolling down his cheeks of Napoleon's wisdom the goodness of his heart, and the deep love he bore to all animals everywhere, ... (p. 47)

2.2.10 Being ubiquitous. Squealer is ubiquitous to find out the views of the animals on the spot in order to give them proper feedback and put things right:

Afterwards Squealer made a round of the farm and set the animals' minds at rest. (p. 37)

And Squealer, who happened to be passing at this moment, attended by two or three dogs, was able to put the whole matter in its proper perspective. (p. 38)

2.2.11 Eloquence. When talking or giving a speech, he usually "cries" (pp. 25, 26, 42, 43, 52) or "exclaims" (p. 43) or "speaks very slowly and firmly" (p. 43) in order to influence the animals and enforce discipline and Napoleon's rules. When crying doesn't work, the dogs as the secret police initiate by growling:

The animals were not certain what the word meant, but Squealer spoke so persuasively, and the three dogs who happened to be with him growled so threateningly, that they accepted his explanation without further questions. (p. 34)

2.2.12 Justification. Squealer always tries to justify the pigs' and especially Napoleon's statements and action. Moreover, one of his duties is to praise the pigs and applaud Napoleon's decisions and actions, that is, appealing to authority. His attempt is to inculcate a deep sense of unquestioning obedience to the pigs and specially Napoleon. In fact, the animals are indoctrinated with a narrow set of (political) beliefs in order not to question their leaders. If the authority states it, then it is true and must be done. Furthermore, he executed the rules and the distortion of the seven commandments very skilfully:

Beasts of England was the song of the Rebellion. But the Rebellion is now completed. The execution of the traitors this afternoon was the final act. . . . Beasts of England we expressed our longing for a better society in days to come. But that society has now been established. Clearly this song has no longer any purpose. (p. 46)

It had become usual to give Napoleon the credit for every successful achievement and every stroke of good fortune. (p. 47)

Napoleon approved of this poem and caused it to be inscribed on the wall of the big barn, at the opposite end from the Seven Commandments. It was surmounted by a portrait of Napoleon, in profile, executed by Squealer in white paint. (p. 48)

But Squealer counselled them to avoid rash actions and trust in Comrade Napoleon's strategy. (p. 49)

But the superior quality of Napoleon's mind, said Squealer, was shown in the fact that he trusted nobody ... (p. 50)

2.2.13 Acting professionally. Like a professional actor, Squealer plays several roles adroitly through the novel including an organizer, a teacher, a supervisor, a counselor, a speaker, a reporter, a commentator, a minister, a politician, a propagandist, a liar and even a priest listening to the confessions:

A gander who had been privy to the plot had confessed his guilt to Squealer and immediately committed suicide by swallowing deadly nightshade berries. (p. 49)

There was, as Squealer was never tired of explaining, endless work in the supervision and organization of the farm. (p. 61)

The sheep spent the whole day there browsing at the leaves under Squealer's supervision. (p. 62)

\subsection{Discourse Analysis}

There have been different viewpoints about the definition of discourse. Different kinds of paradigms provide different assumptions about the general nature of discourse. These paradigms are sometimes differently labeled. These differences in paradigms influence definitions of discourse. The first paradigm is Newmayer's (1980) formalist paradigm which views discourse as "sentences" (Schiffrin, 1994, p. 20). Schiffrin holds that the second paradigm is the functional paradigm and it is sometimes called emergent or interactive paradigm which views discourse as language use. There is also a third definition of discourse provided by Schiffrin that attempts to bridge the formalist-functionalist dichotomy.

The functional paradigm of discourse which is the focus of this paper regards language as a social phenomenon, that is, language use. This definition observes the relationship the discourse has with the context. The functionalist paradigm is based on two general assumptions: (a) Language has functions that are external to the linguistic system itself (b) External functions influence the internal organization of the linguistic system (p. 20). Consequently, functionalists such as Halliday tend to regard language as a social phenomenon and explain linguistic universals as deriving from the universality of the uses to which language is put in human society (Geoffrey, 1983). However, discourse Analysis is the 
deconstructive reading and interpretation of a text to reveal the hidden motivations behind a text.

\subsection{House's Discoursal Revisited TQA Model}

The model (House, 1977, 2nd ed. 1981) is based on "pragmatic theories of language use", and it provides for the analysis of the "linguistic discoursal" as well as the "situational-cultural particularities of the source and target texts", a comparison of the two texts and the resultant assessment of their relative match (House, 1997, p. 29). House maintains that the revised model draws mainly “on pragmatic theory, on Halliday's functional and systemic theory, on notions developed inside the Prague school of language and linguistics, on register theory and stylistics as well as discourse analysis". In other words, House's discourse and register analysis approaches are based on the model of Hallidayan systemic functional linguistics which links "microlevel linguistic choices to the communicative function of a text and the sociocultural meaning behind it" (Munday, 2008, p. 104).

Based on the model of language in context known as systemic functional linguistics (SFL) (Halliday \& Martin, 1993/1996/2005, and Halliday \& Webster, 2009), Martin (2009, p. 11) believes that "this model involves a rich conception of language as a meaning-making system, involving phonology/graphology, lexicogrammar, and discourse semantics".

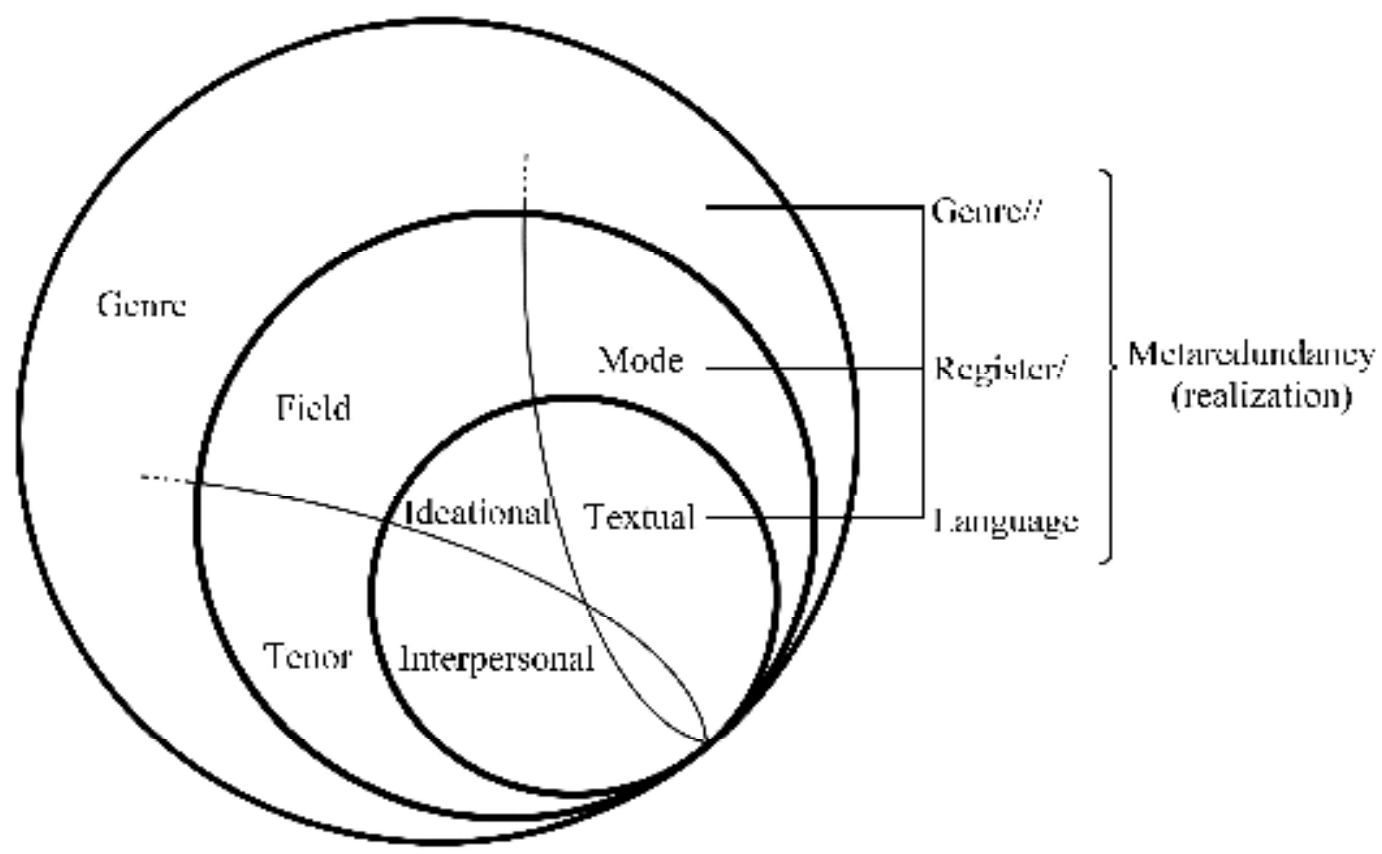

Figure 1. Metafunction in Relation to Language, Register and Genre (Martin, 2009, p. 12)

According to Martin (2009), Figure 1 illuminates that:

One of the reasons for separating genre from field, tenor, and mode was to allow for shifts in field, tenor, and mode variables from one stage of a genre to another (e.g., being friendly in the beginning of a service encounter and then toughening up to close the sale). (p. 12)

In adaptation of Martin (1993, p. 120), Figure 2 illustrates House's (1997, 2009) scheme for analyzing and comparing original and translation texts and assessing their functional equivalence.

\begin{tabular}{|c|c|c|}
\hline $\begin{array}{l}\text { RF(ils'l'R } \\
\left(U_{s t} \text { ol }(\mathrm{w} x)\right.\end{array}$ & $\begin{array}{l}\text { INIDVIIDUAI, I'FXI'S } \\
\text { IUINCIIONAL PROIILE: }\end{array}$ & $\begin{array}{l}\text { (IFNRF } \\
\text { (IYpe of } 1 \mathrm{Lx} 1)\end{array}$ \\
\hline \multicolumn{3}{|c|}{4} \\
\hline $\begin{array}{l}\text { ГТГТ.Г) } \\
\text { What the text is about. What } \\
\text { kinds of things are in the } \\
\text { (sxl? }\end{array}$ & $\begin{array}{l}\text { TINOR } \\
\text { IIow the author, the reader, and } \\
\text { maybe the persons in the texL, relate } \\
\text { to savh other through the lixi. }\end{array}$ & $\begin{array}{l}\text { МОГТТ } \\
\text { IIow the text is communicated: } \\
\text { how its patts lit together as text. }\end{array}$ \\
\hline & 4 & 7 \\
\hline & $\begin{array}{l}\text { A SPLCHIC ILXI } \\
\text { The words, and any non- } \\
\text { xerbal conterit. }\end{array}$ & $\begin{array}{l}\text { CULILRAL CONLEXIS Whi工 } \\
\text { and why the text was composed? }\end{array}$ \\
\hline
\end{tabular}

Figure 2. A Scheme for Analyzing, Comparing and Assessing Functional Equivalence. (House, 2009, p. 35) 


\subsection{Register Analysis}

The result of the analysis according to House's scheme is a textual profile which in its entirety can be taken to characterize the register of a particular text, that is, the way the text is in relation with particular contextual factors. As it was observed in House's (1997) Scheme for analyzing and comparing original and translation texts, register consists of three subcategories: field, tenor and mode. Field refers to:

the nature of the social action that is taking place, it captures what is going on, that is, the field of activity, the topic, the content of the text or its subject matter. The degrees of generality, specificity or granularity in lexical items according to rubrics of specialized, general, popular are differentiated which however specifies some features that will now be subsumed under Genre. (pp. 108-109)

Tenor refers to who is taking part, to the nature of the participants, the addresser and the addressees, and the relationship between them in terms of social power and social distance, as well as the "degree of emotional charge" in the relationship between addresser and addressee(s) (Halliday, 1978, p. 33). Mode refers to the channel of communication, the spoken or written medium, with many in-between possibilities such as "written to be read", or "written to be spoken as if not written" (House, 2009, p. 34). In taking account of the differences in texts between the spoken and the written medium, when appropriate, the empirically established (corpus-based) oral-literate dimensions -dimensions along which linguistic choices may reflect medium- are taken into considerations (House, 1997, pp. 108-109). These parameters are as follows: (a) Involved versus informational text production, (b) Explicit versus situation-dependent reference (c) Abstract versus non-abstract presentation of information.

\subsection{Overt versus Covert Translation}

Equivalence is one of the main concerns of translators especially with respect to overt and covert translations. House (2009, p. 13) believes that the three basic features of translation are "text, equivalence, and process". Taking equivalence as the fundamental criterion for translation quality, "an adequate translation text is a pragmatically and semantically equivalent one" to the function of its original (House, 1997, pp. 31-32). She sheds more light on overt translations as follows:

Functional equivalence between the two texts is in principle possible, but . . . is different in nature: it [gives] the new readers access to the function of the original. ... [Therefore], a switch in the discourse world becomes necessary, such that the translation operates in its own discourse world. . . . [This is] called second-level functional equivalence. (2009, pp. 36-38)

By contrast, with respect to covert translations, House (pp. 37-38) maintains that since "full functional equivalence" is aimed at, the original may be "manipulated at the levels of text and register" via the use of "a cultural filter". A cultural filter is applied in covert translations in order to "account for cross-cultural differences in the expectation norms holding in the two cultures concerned" (1997, p. 95). The result may be a very real distance from the original. Focusing on the notion of "cultural filter", House highlights that:

In aiming at "originality", the translator will employ a "cultural filter" to compensate for culture specificity. With this filter, the translator makes allowances for culture specificity accommodating for differences in sociocultural conventions and communicative preferences. It is recommended that the use of a cultural filter be based on empirical research into language pair-specific cultural differences, and not left entirely to unverified assumptions. (2010, p. 246)

Table 1 comparatively elaborates on the significant and exclusive features of overt versus covert translation more clearly and tangibly. ST, TT and TC in this table stand for source text, target text and target culture respectively.

Table 1. Overt versus Covert Translation, Adopted from House (1997, 2009, 2010)

\begin{tabular}{ll}
\hline Overt translation & Covert translation \\
\hline $\begin{array}{l}\text { It is equivalent at the levels of text, register, and } \\
\text { genre. }\end{array}$ & $\begin{array}{l}\text { It is equivalent at the levels of genre and the } \\
\text { individual text's functional profile, i.e. what the text } \\
\text { can mean for a target reader. }\end{array}$ \\
\hline It operates quite overtly as a translation. & $\begin{array}{l}\text { It operates quite overtly in TT/TC discourse world } \\
\text { not as a translation but as a second original. }\end{array}$ \\
\hline $\begin{array}{l}\text { It is marked semantically and pragmatically a } \\
\text { translation. }\end{array}$ & It is not marked pragmatically as a translation. \\
\hline $\begin{array}{l}\text { ST elements shine through TT. } \\
\text { There is second level or second-hand or partial } \\
\text { functional equivalence. }\end{array}$ & $\begin{array}{l}\text { There is full or primary or real functional } \\
\text { equivalence. }\end{array}$ \\
\hline $\begin{array}{l}\text { Function of ST discourse world to TT readership is } \\
\text { accessible, i.e. the readership can afford to eavesdrop } \\
\text { at a lingua-cultural distance, appreciate the original } \\
\text { textual function and observe and/or judge TT from } \\
\text { outside. }\end{array}$ & $\begin{array}{l}\text { Function of ST discourse world to TT readership is } \\
\text { inaccessible, i.e. the readership fails to keep track of } \\
\text { ST lingua-cultural or ST discourse world. }\end{array}$ \\
\end{tabular}


It co-activates ST discourse world, i.e. a switch in the discourse world occurs.

It is more straightforward, i.e. ST is taken over without sociocultural modification.

Cultural filtering is withheld, i.e. ST is not distorted at the levels of text and register.

\begin{tabular}{|c|c|}
\hline $\begin{array}{l}\text { It is embedded in a new speech event in the target } \\
\text { culture. }\end{array}$ & $\begin{array}{l}\text { It enjoys the status of ST in the target language } \\
\text { culture. }\end{array}$ \\
\hline It is close to the original culture. & It is distant from the original culture. \\
\hline ST must remain as intact as possible in TT. & ST is transmuted in translation and TT is misleading. \\
\hline There is a linguistic-cultural transfer. & It operates exclusively in the new target culture. \\
\hline TT audience is not directly addressed. & ST is not specifically addressed to a TC audience. \\
\hline $\begin{array}{l}\text { It is psycholinguistically more complex and not } \\
\text { deceptive. }\end{array}$ & $\begin{array}{l}\text { It is psycholinguistically less complex and more } \\
\text { deceptive. }\end{array}$ \\
\hline $\begin{array}{l}\text { It is a case of language mention resembling a } \\
\text { quotation. }\end{array}$ & ST and TT differ only accidentally in their languages. \\
\hline Translator's task is not to cheat but to be visible. & Translator's task is to cheat and be invisible. \\
\hline $\begin{array}{l}\text { It is linguistically and psycholinguisticly of a } \\
\text { distinctly hybrid entity. }\end{array}$ & It is of a homogeneous entity. \\
\hline Texts that should be translated overtly: & Texts that should be translated covertly: \\
\hline $\begin{array}{l}\text { Documents of historical events and texts considered } \\
\text { sacrosanct; Literary texts (e.g. fairy tales and so } \\
\text { forth); Culture specific texts; Speeches by famous } \\
\text { personalities at a certain time and in a certain place. }\end{array}$ & $\begin{array}{l}\text { Transitory texts designed for ready consumption (e.g. } \\
\text { instructions, commercial circulars, advertisements, } \\
\text { journalistic and scientific texts); The Bible; Non- } \\
\text { culture specific texts. }\end{array}$ \\
\hline
\end{tabular}

It recreates, reproduces or represents an original text/an equivalent sociocultural event, i.e. it hides ST's real origin.

Different discourse worlds of ST and TT cultures are considered.

Cultural filtering is applied, i.e. ST is manipulated at the levels of text and register to compensate for culture specificity.

It enjoys the status of ST in the target language culture.

ST is transmuted in translation and TT is misleading.

ST is not specifically addressed to a TC audience.

It is psycholinguistically less complex and more deceptive.

Whether an original text is translated overtly or covertly depends upon many criteria. For example, in Table 1, it is suggested that a literary text should be translated overtly. However, it might be translated covertly, to a certain extent, based on some reasons, ideologies and philosophies.

\section{Corpus and Method}

In this paper, the only existing English-Azarbaijani Turkish translation of the excerpt of Squealer's speech from Orwell's Animal Farm (1945, pp. 33-34), through a qualitative method, was discoursally analyzed based on House's (1997, 2009) revised TQA model. The translation was by Guliyev and Rahim Zadeh Faraji (2010, p. 42). In fact, the second translator, who is an Iranian, translated it from Guliyev's Azerbaijani Turkish translation of Animal Farm. That is, the text is almost the same but it is in Persian alphabet. According to House's model, literary translations must be translated overtly to meet the standards of an adequate translation. In other words, translation of speeches as propaganda in literary texts is adequate if they are translated overtly. Such an overt translation should be equivalent at the levels of text, register, and genre in order to successfully co-activate the original discourse world. Furthermore, the covertly and overtly erroneous errors in the translation of speeches should be as few as possible. On the other hand, the purpose of this study is to investigate the ideological impact on the target text's readership by the comprehensive analysis of the original text and its translation. The discovered covertly and overtly erroneous errors disclose the hidden ideologies embedded by the translators and discover the distorted and manipulated ideologies of the original in the translation. First, the mismatches and differences along the analysis of the textual profiles of the source and target texts reveals the covertly erroneous errors. Second, the overtly erroneous errors are found through the in-depth analysis of the texts. These two types of errors are found out in order to see to what extent a translation is adequate. In other words, a translation text, in order to be "adequate", is to fulfill the requirement of a dimensional, and as a result of this, a functional match, then "any mismatch along the dimensions is an error" (House, 1997, p. 45). Such dimensional errors which are called "covertly erroneous errors" demand "a much more qualitative-descriptive, in-depth analysis" than "overtly erroneous errors" resulted either from two subcategories as follows: (a) mismatches of denotative meanings of ST and TT elements: omissions, additions and substitutions (i.e. wrong selections or wrong combinations of elements); (b) breaches of the target language system: ungrammaticality, that is, clear breaches of the language system, and cases of dubious acceptability, that is, breaches of the norm of usage defined as a bundle of linguistic rules underlying the actual use of language (as opposed to the language system concerning with the potentialities of a language).

\section{Data Analysis}

Since the whole translation of Squealer's speech is considered problematic, the whole excerpt appeared along with its Turkish translation and the translation's IPA-transcription, transliteration and back-translation respectively. In this section, Squealer's speech paralleled its Azarbaijani Turkish translation sentence by sentence in order to be compared 
and analyzed. For the ease of reference and application, only the number of the sentences was given. The translation was by Guliyev and Rahim Zadeh Faraji (2010, p. 42). The Turkish-English transliteration and back-translation of the translation are conducted by the authors of this paper who are native Turkish. In this regard, Azerbaijani Language Explanatory Dictionary (Orujovun, et al, 2006) was very helpful and is fully appreciated.

Sentence 1.

ST: "Comrades!" he cried.

$$
\text { TT يولداشلار ! دئيه او، زيل سسى ايله قيشقيرماغا بانشلادى. TT }
$$

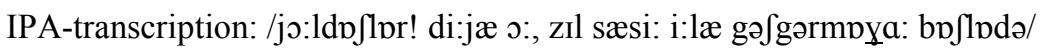

Transliteration: Comrades! Said he, with a high voice yelling started.

Back-translation: Comrades! Said he, started yelling with a high voice.

In the first sentence, the word "cry" was translated into six words! This is a case of substitution, verbiage and unnecessary addition, that is, illegitimate semantic expansion. It should be underlined that verbiage refers to "a profusion of words usually of little or obscure content" (Merriam-Webster, 2014). This strategy has been applied to the translation several times which makes the target readership's comprehension process difficult and more complicated.

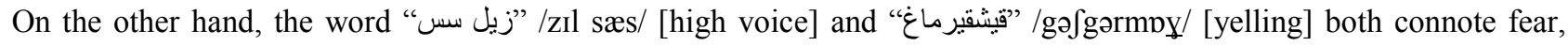
fright and scare. In contrast, this sentence is the beginning of the speech by the person in authority. That is, the power relations were highly distorted and manipulated. This means that the position of authority was belittled and consequently humiliated. This is a case of manipulation of social role relationship.

Sentence 2.

ST: You do not imagine, I hope, that we pigs are doing this in a spirit of selfishness and privilege?

TT : - اوميد ائديرمكى، دونوزلارين بو حركتينى اونلارين تكجه اؤزلرينى بينمه، يا خود اؤزلرينى باثقالاريندان آرتيق حساب ايتمه لرى ايله علاقه لندير ميه جكسينيز.

IPA-transcription: /ümıd edıræmki:, do:nu:zlprən bo hærækætıni: s:nlprən tækdłæ øzlærıni: bæjænmæ, ja: xo:d øzlærıni: bofgplprındpn $\Lambda$ rtəg hesa:b etmælæri: i:læ æla:gælændırmæjæ dzæksınız/

Transliteration: hope I the pigs' behavior as their pride or selfishness would not be considered.

Back-translation: I hope the pigs' behavior would not be considered only as their pride or selfishness.

In the second sentence, the clause "You do not imagine," was omitted from the translation while it was foregrounded in the source text. In other words, before stating the pigs" "selfishness and privilege", Squealer intended to modify the negative aspects of the pigs' character traits by this clause at the beginning. In fact, the original sentence foregrounded that there should not be any doubt about the pigs' sincerity and honesty. Therefore, this omission led to an ideological distortion in the translation and consequently in its effect on the target readership. On the other hand, the addition of the word "تكجه"/tækdzæ/ [only, just] led to the distortion of meaning so that it distorted the message of the original dramatically. In other words, the original sentence denotes that the pigs have never been selfish and privileged. On the contrary, the translation indicates that a spirit of selfishness and privilege is of the pigs' intrinsic nature and personality. This is exactly the opposite message of the original. Moreover, it is perceived from the source text that Squealer was a member and speaker of the pigs' community by using the first person pronouns "I" and "we". In contrast, his identity was lost in the translation as if he was just a speaker or a narrator. Hence, he was an authority figure in ST but adopted a neutral position in TT. In other words, the social role relationship and interpersonal function of the original were totally manipulated in this sentence.

Sentence 3 .

ST: Many of us actually dislike milk and apples.

$$
\text { TT : اصلينده جوخوموزون سودن و آلمادان خوشو كلمبر. }
$$

IPA-transcription: /æslindæ to:x

Transliteration: actually many of us of milk and apple like not

Back-translation: Actually, many of us don't like milk and apples.

Thematic movement or the theme-rheme (i.e. given-new ordering) distribution of this sentence has been distorted. House (1997) maintains that "word order is the primary formal means of realizing the theme-rheme distribution: in normal, unmarked speech, the theme precedes the rheme (objective position), in emotive speech, however, the rheme precedes the theme (subjective position)" (p. 44). The theme-rheme organization of each and every statement differs depending upon a variety of criteria including the discoursal and ideological aspects of the text and author's perspective. On the other hand, "dislike" in ST and "don't like" in TT do not meet the same meaning components. "Dislike" is sharper, more influential, straightforward and inconsiderate than "don't like" which is more moderate, milder and considerate. 
ST: I dislike them myself.

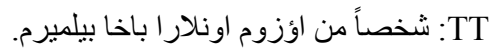

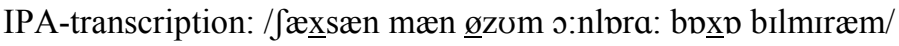

Transliteration: Personally, I myself at them cannot look.

Back-translation: Personally, I myself cannot look at them.

In the fourth sentence, the expression "باخا بيلميرم" /bpxp bilmiræm/ [I cannot look] as the equivalent of "I dislike” has been ambiguously translated and wrongly substituted.

Sentence 5.

ST: Our sole object in taking these things is to preserve our health.

$$
\text { آلما و سوددن ايستيفاده دن يحانه مقصد ساغلامليغيميزى قوروماقلا باغليدير. TT }
$$

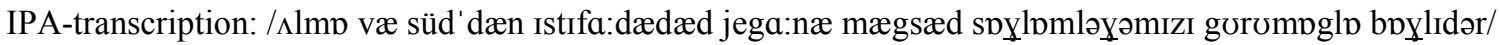

Transliteration: of apple and milk consuming the only object our health is to preserve.

Back-translation: The only object of consuming apple and milk is to preserve our health.

The textual function was manipulated in the translation of the fifth sentence. The word "things" was translated into " آلها " و سود / / $1 \mathrm{lmb}$ væ süd/ [apple and milk]. This is a wrong selection of words and an ideological distortion of the original. Moreover, by using "things" instead of its antecedent in the source text, the attention of the sentence was intentionally diverted away from "milk and apples" into the pigs' sole object, that is, preserving their health. Therefore, the attention of the target readership would be paid to "milk and apples" instead.

Sentence 6.

ST: Milk and apples (this has been proved by Science, comrades) contain substances absolutely necessary to the well-being of a pig.

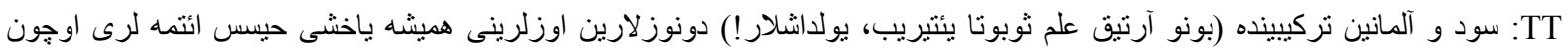
ضرورى او لان مادده لر و واردير.

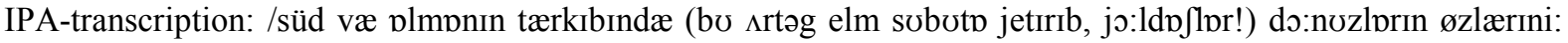

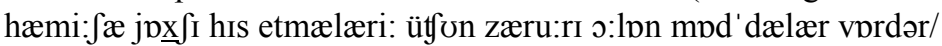

Transliteration: milk and apple in combination its (this actually science proof made, comrades!) pigs' themselves of always good feeling making for necessary be substances exist

Back-translation: In the combination of milk and apples (science actually proved this, comrades!) there are necessary substances for the pigs to always feel good.

The expression "well-being" refers to "the state of being happy, healthy, or prosperous" (Merriam-Webster, 2014). These meaning components which are mainly absent in the translation are found in the Turkish terms " ريفاه، سلامنليك، "2017) " "اوغور /rifph, sæla:mætlık, o:yor/ (Orujovun, et al, 2006). In other words, the connotation of the term "well-being" was manipulated and led to the semantic distortion of the original.

Sentence 7.

ST: We pigs are brainworkers.

TT بيز دونوز لار عقلى فعاليتله مشغولوق.

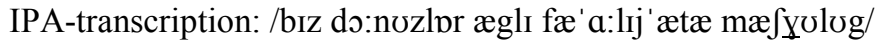

Transliteration: we pigs wise actions of busy are

Back-translation: We pigs are busy with wise actions.

There is a considerable ideological and discoursal distortion in the seventh sentence. "Brainworkers" and " عقلى فعاليتله

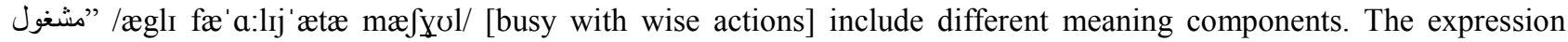
"wise actions" in the translation refers to just simple activities which necessitates being sensible. By "brainworkers", Orwell foregrounded a set of class divisions occurring in (totalitarian) societies: the intellectuals and laborers [emphasis added]. Thus the pigs as "brainworkers" and intellectuals use their superior intelligence to control and manipulate society to their own benefit (SparkNotes, 2007). This website holds that "the novella points to the force of this tendency toward class stratification in many communities and the threat that it poses to democracy and freedom". 
Sentence 8 .

ST: The whole management and organization of this farm depend on us.

$$
\text { TT: زمى ده كى بونون ايداره جيليك و تشكيلاتى ايشلرين مسئوليتينى داشيييريق. }
$$

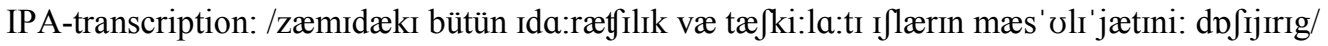

Transliteration: the field's all management and organizational jobs responsibility take we.

Back-translation: [We] take responsibility for the field's all management and organizational jobs.

In the eighth sentence, the word "زمى"/zæmI/ [field] does not match all the meaning components of the word "farm". One of the ideological connotations of the term "farm" refers to "a district or division of a country leased out for the collection of government revenues" (Merriam-Webster, 2014). This connotation foregrounds the power relations and inspires the readership with the existence of authority. In fact, "farm" was downgraded in the translation whereas it is foregrounded in the original.

Sentence 9 .

ST: Day and night we are watching over your welfare.

$$
\text { TT كئجه - كوندوز سيزين ريفاهينيزين كئشييينده دايانيريق. }
$$

IPA-transcription: /gedłæ gündüz sızın rıfa:hınız ke Ijıındæ dpjpnərəg/

Transliteration: night and day your welfare are supporting [we].

Back-translation: Day and night, [we] are supporting your welfare.

The pronoun "we", in the ninth sentence, was translated into the person suffix "يق"/g/, while it could have been translated into its proper equivalent "بيز" /biz/ instead. In other words, the pronoun "we" was downplayed and consequently the pigs were belittled. This is also an ideological distortion of meaning of the source text in the translation.

Sentence 10 .

ST: It is for your sake that we drink that milk and eat those apples.

$$
\text { TT }
$$

IPA-transcription: /jplnəz sızın rıfa:hınız üffün bo südü itfır, bø plmplprı jejırık/

Transliteration: only your well-being your for this milk drink, this apples eat we

Back-translation: We drink this milk and eat these apples only for your welfare.

The expression "for your sake" was translated into "سيزين ريفاهينيز اوجون" /sızın rifa:hınız ütün/ [for your well-being]. The original phrase has a more general meaning whereas the translation restricted that meaning to just limited aspects of the animals' improvement, that is, welfare. However, the expression "for your sake" has a wide positive connotation and means "in order to help somebody/something or because you like somebody/something" (OUP, 2014).

Sentence 11.

ST: Do you know what would happen if we pigs failed in our duty?

$$
\text { TT اكر دونوز لار اؤز وظيفه لرينى يئرينه يئتيرمك قودرتينده اولماسالار بونون نه ايله نتيجلنه جه يينى بيلير سينيزمى؟ }
$$

IPA-transcription: /ægær do:nuzlpr øz væzi:fælærıni: jerınæ jetırmæk gudrætındæ ॰:lmbsplpr bonひn næ i:læ nætıḑælænæ dzæ jıni: bilırsınızmı?/

Transliteration: if pigs their duties its place take strength are not this's actually consequences their do you know?

Back-translation: If the pigs can't do their duties, do you know [what will be] the consequences?

The original sentence is a conditional one. Conditional sentences are used to express that the action in the main clause can only take place if a certain condition is fulfilled. In ST, the independent or main clause which expresses the consequence leads the sentence and holds the readers' attention on until reading the dependent or if clause. Moreover, for the independent clause is a question, the readers' concern and attention increase dramatically. In contrast the clauses interchanged their position in TT. Thus discoursally the social effect totally changed. This means that the foregrounding mechanism of ST was heavily distorted in TT. House (1997, p. 43) defines foregrounding [in contrast with automatization] as "a linguistic device for making the reader conscious of a particular linguistic form such that the linguistic form itself attracts attention, and is felt to be unusual or de-automatized".

On the other hand, the original is a conditional sentence type two which refers to situations in the present. It is possible but very unlikely that the condition will be fulfilled as though it is imaginary. That is, there is no expectation to change 
the situation. Discoursally, by the time the animals learned about the decision, they were already presented with a fait accompli. In other words, the decision has already been made without involving the animals in the decision-making process. In fact, the animals are left with no option but to accept it. Hence the animals did not even have a minor role in the decision-making. However, the translation is a conditional sentence type one which refers to the future. It is possible and also very likely that the condition will be fulfilled. That is, the conditions seem rather realistic. From the translation, it can be inferred that the animals have a role in the decision-making process. This is in contrast with the message of the original.

Sentence 12 .

ST: Jones would come back!

$$
\text { TT }
$$

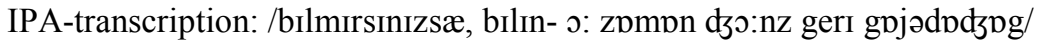

Transliteration: if you don't know, know- that time Jones will come back.

Back-translation: Know, if you don't know-that time Jones will come back.

In the twelfth sentence, the clause “بيلميرسينيزسه، بيلين" /bilmirsinizsæ, bilin/ [if you don't know, know!] was added unnecessarily to the translation. From discourse point of view, this addition indicates that Squealer treated the audience with contempt and consequently there would be an ideological manipulation of the social effect on the target readership. Regarding the translation of "would" into "will", see the discussion of sentence 11.

Sentence 13.

ST: Yes, Jones would come back!

IPA-transcription: /bælı dəo:nz jenıdæn gerı gpjədbdъpg/

Transliteration: yeas, Jones again back come back.

Back-translation: Yes, Jones will come back again.

Sentence 13 is for underlining sentence 12 in answering the question in sentence 11 . See the discussion of sentence 11.

Sentence 14.

ST: Surely, comrades, cried Squealer almost pleadingly, skipping from side to side and whisking his tail, "surely there is no one among you who wants to see Jones come back?"

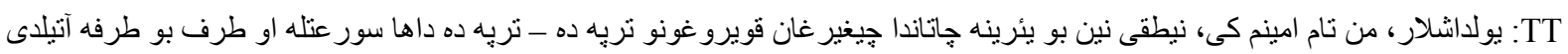

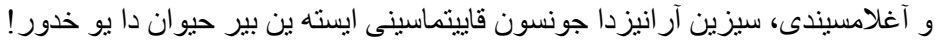

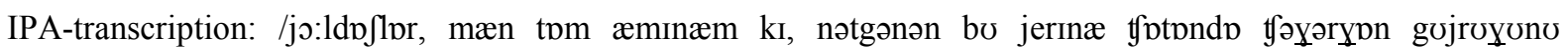

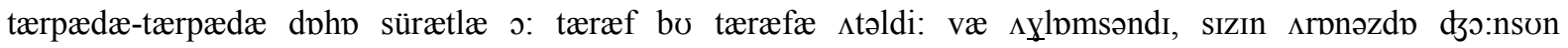
gojətmpsəni: Istæ jæn bir hejvon do jo:x́ür!/

Transliteration: Comrades, I definitely sure am that his speech to this part of he came, screaming his tail whisking quickly from side to side skipping and was on the verge of tears, your among Jones' come back even want one animal not.

Back-translation: Comrades, I am definitely sure, when he came to this part of his speech, screaming and whisking his tail, skipping from side to side was on the verge of tears, even one animal is not among you to want Jones come back.

In the last sentence, there was a huge manipulation. First, the name of the speaker "Squealer" was omitted from the translation while it appeared once in the speech and in the last sentence for its significance. The clause "نيطقى نين بو يئرينه جاتاندا" /nətgənən bo jerınæ fptondp/ [when he came to this part of his speech] was added to the translation. Furthermore, the word "آغلامسيندى" / إيlpmsəndI/ [was on the verge of tears] is not a proper but a misleading Turkish equivalent of the adverb "pleadingly" meaning "in an emotional way that shows that you want something very much but are not certain that somebody will give it to you" (OUP, 2014). The expression "بير حيوان دا" "bir hejvpn dp/ [even one animal] was wrongly substituted for "no one" in which no indication of discrimination or social classification is perceived. Finally, the verb "see" was omitted from the translation. "See" means "to imagine that something may happen in the future" (LDOCE, 2009). It is clear that the original sentence denotes that nobody wants to imagine that one day Jones will come back. This concept is absent in the translation.

\section{Results and Discussion}

The covertly erroneous errors are found out in the analysis of the source and target text profiles. The significant categories considered in this analysis were register analysis, function, genre, and the comparison of the original and translation at the level of language/text. Accordingly, Table 2 demonstrates comparatively the in-depth analysis of the 
source text and its translation more tangibly under the categories of register, function and genre.

Table 2. Comparison of ST and TT Register Analysis

\begin{tabular}{|c|c|c|c|}
\hline \multicolumn{2}{|c|}{ Register Categories } & \multirow{2}{*}{$\begin{array}{l}\text { ST } \\
\text { An allegorical, sociopolitical, ideological and anti- } \\
\text { totalitarian fable, an anti-utopian satire; Squealer's } \\
\text { speech/Propaganda }\end{array}$} & \multirow{2}{*}{$\begin{array}{l}\text { TT } \\
\text { A relative } \\
\text { match }\end{array}$} \\
\hline Field & Subject matter & & \\
\hline & Social action & General/Popular & $\sqrt{ }$ \\
\hline \multirow[t]{3}{*}{ Tenor } & $\begin{array}{l}\text { Author's provenance } \\
\text { and stance }\end{array}$ & $\begin{array}{l}\text { A British political novelist and essayist with pointed } \\
\text { criticisms of political oppression }\end{array}$ & $\sqrt{ }$ \\
\hline & $\begin{array}{l}\text { Social role } \\
\text { relationship }\end{array}$ & Asymmetrical & $\begin{array}{l}\text { Distorted in } \\
\text { many cases }\end{array}$ \\
\hline & Social attitude & Informal & Less informal \\
\hline \multirow[t]{2}{*}{ Mode } & Medium & $\begin{array}{l}\text { Simple/Written to be read-informational text, } \\
\text { Situation-dependent, Non-abstract information }\end{array}$ & $\sqrt{ }$ \\
\hline & Participation & Complex & $\sqrt{ }$ \\
\hline
\end{tabular}

It was discussed that the category of register consists of three major subcategories: field, tenor and mode. According to Table 2, by comparing the source text and its translation, it can be claimed that there is no considerable match between the categories of register. The function of the source text is ideational and its genre is novel/fiction/fable/fairy tale/allegory/satire/speech/propaganda. Comparing the function and genre of the texts, the translation holds a relatively distorted match. It must be mentioned that the social role relationship and social attitude, the two subcategories of tenor, were distorted in many cases. Moreover, the mismatches between the source text and the translation in lexical, syntactic and textual means were illustrated in table 3.

Table 3. Mismatches between ST and TTs' Profiles in Lexical, Syntactic and Textual Means

\begin{tabular}{lll}
\hline Category & ST & TT \\
\hline Lexical means & No archaic expressions & $\sqrt{ }$ \\
\cline { 2 - 3 } & No idiomatic expressions & More idiomatic expressions-verbiage \\
\hline Syntactic means & Simple-complex sentences & $\sqrt{ }$ \\
\hline Textual means: & Strong textual cohesion & Not as strong as ST \\
\hline (a) Clausal linkage & More & $\sqrt{ }$ \\
\hline (b) Iconic linkage/structural parallelism & Strong & Very weak \\
\hline (c) Theme dynamics & Strong & $\sqrt{ }$ \\
\hline & Note. $\sqrt{ }=$ (Relative) Match &
\end{tabular}

Concerning the mismatches between the source text and the translation in lexical, syntactic and textual means, a relative match between ST and TT is observed. Some differences were found in the subcategories of the lexical, syntactic and textual means. These differences and mismatches led to the socio-ideological manipulation of the original in the translation. As an example, in the fifth sentence of Squealer's speech, "milk and apples" as the pigs' most important food was downgraded by the substituted neutral word "things" in the middle of the sentence. In contrast, "الما و سود" " " " / $\mathrm{lmb} v æ$ süd/ [apple and milk] was used instead of "things" in the translation and foregrounded, appearing just at the beginning of the sentence!

Table 4 highlights the analysis of the translation at the level of Language/Text. In this respect, four categories were discussed as follows: word, clause, sentence and paragraph. The categories were distinguished based on Richards and Schmidt's definitions (2002): (a) Word is the smallest of the linguistic units which can occur on its own in speech or writing and in writing, word boundaries are usually recognized by spaces between the words (p. 588). (b) Clause is a group of words which form a grammatical unit and which contain a subject and a finite verb. A clause forms a sentence or part of a sentence and often functions as a noun, adjective, or adverb. Clauses are classified as dependent or independent (pp. 74-75). (c) Sentence is the largest unit of grammatical organization within which parts of speech (e.g. nouns, verbs, adverbs) and grammatical classes (e.g. word, phrase, and clause) are said to function. In English, a sentence normally contains one independent clause with a finite verb (p. 480). (d) Paragraph is a unit of organization of written language in many languages, which serves to indicate how the main ideas in a written text are grouped. In text 
linguistics, paragraphs are treated as "indicators of the macro-structure of a text". They group sentences which belong together, generally those which deal with the same topic and therefore a new paragraph indicates "a change in topic or sub-topic" (pp. 382-383).

Table 4. Comparison of ST and TT at the Level of Language/Text

\begin{tabular}{lllll}
\hline Item & ST & TT & Difference (No.) & Difference (\%) \\
\hline Word & 155 & 154 & -1 & $0.6 \% \downarrow$ \\
Clause & 27 & 28 & +1 & $3.7 \% \uparrow$ \\
Sentence & 14 & 15 & +1 & $7.1 \% \uparrow$ \\
Paragraph & 1 & 1 & 0 & $0 \%$ \\
\hline
\end{tabular}

Note. $\downarrow=$ Decrease, $\uparrow=$ Increase

With a focus on Table 4, we observe that there is a full match between ST and TT in the category of paragraph. In other words, one paragraph in ST was translated into one paragraph in TT. Moreover, in the cases of word, clause and sentence, there is a relative match between the texts. Therefore, the unit of translation in TT was paragraph and relatively word, clause or sentence. Furthermore, Table 5 sheds more light on the overtly erroneous errors of the translation in five specific categories of omissions, additions, substitutions, ungrammaticality, dubious, acceptability.

Table 5. TT Overtly Erroneous Errors, Adopted from House (1997, p. 45)

\begin{tabular}{lll}
\hline General & Specific & TT \\
\hline A mismatch of denotative meanings of ST and TT elements & Omissions & 6 \\
\cline { 2 - 3 } & Additions & 3 \\
\cline { 2 - 3 } & Substitutions & 11 \\
\hline The breaches of the target language system & Ungrammaticality & 0 \\
\cline { 2 - 3 } & Dubious acceptability & 0 \\
\hline Total number of TT overtly erroneous errors & & 20 \\
\hline
\end{tabular}

It is observed that the overtly erroneous errors were mainly in the mismatches of denotative meanings of the source and target text elements. Furthermore, the distortions were very high in the subcategory of substitutions.

\section{Conclusions}

The purpose of this study was the translation quality assessment of Squealer's speech as propaganda. With regard to covertly and overtly erroneous errors, the findings of the study demonstrated that considerable distortions and ideological manipulation were carried out in the Turkish translation. In other words, the translation was not free from but pregnant with ideological manipulation. Some of the distortions were so huge that the core message of the original was totally manipulated ideologically. By the analysis and comparison of the texts in details, it was observed that there was no significant match between the texts in register categories, function and genre. Regarding lexical, syntactic and textual means, many cases of ideological manipulation were discovered.

House (1997, p. 41) subdivided Crystal and Davy's dimension status into two categories: social role relationship and social attitude. Under social role relationship [emphasis added], the role relationship is analyzed between addresser and addressees, which may be either symmetrical (i.e. marked by the existence of solidarity or equality) or asymmetric (i.e. marked by the presence of some kind of authority). Social role relationship is also subcategorized into author-reader(s) and author-characters. However, regarding Squealer's speech in Animal Farm, author-reader(s) relationship in ST is asymmetric, that is, marked by the presence of some kind of authority. Furthermore, author-characters relationship in ST is asymmetric too because it is the author who introduces the characters, suggests the roles, and upgrades or downgrades the characters' position. On the other hand, the purpose of the story is not admiring and approving but criticizing and disapproving. For example, Orwell portrays Squealer as an unpleasantly deceitful figure with a persuasive argument and refrains from idealizing his character, making sure to endow him with certain moral defects. In fact, this literary text is mainly "a reflection of its author's life and times" and "the life and times of the characters in the work" (Wilfred, et al, 2005, p. 51). It must be mentioned that based on the discoursal analysis of the textual profiles of the texts, it is claimed that the social role relationship was hugely distorted in the Turkish translation.

With respect to social attitude [emphasis added], the source text is of friendly informal style in that Orwell does not apply sentiment or flowery language, that is, he uses not complicated and rare words but simple clear language, simple and powerful. However, Orwell was deeply suspicious of intellectuals and it is clearly learned that the pigs were so shady. Being doubtful about bewilderingly complicated arguments and fancy writing, Orwell worked out that people could use such a speaking or writing style to disguise unpleasant and immoral actions. Loss of informal style in most 
instances of the translation reduced the satirical effect. The use of less informal words and even some archaic expressions exacerbated the situation in the translation. In other words, the style level is in certain instances less informal and less designed to communicate closeness in the target text.

With regard to function as a fundamental principle of language and among many different classification schemes for the functions of language, House (1997, pp. 35-36) adopts Halliday's labels of textual, ideational and interpersonal functions through which language makes links with itself and with the situation. The ideational function with its experiential and logical functional components is a referential or content oriented function, that is, a cognitive and an expressive/emotive-conative function. A descriptive or ideational function organizes a speaker's or writer's experience of the world and conveys information which can be stated or denied and in some cases tested (Richards \& Schmidt, 2002, p. 217). In contrast, the interpersonal function is a non-referential function, that is, cognitive (or denotative) meaning including concepts which people have with regard to the content of verbal communication, and emotive, connotative meaning covering the emotional reactions which people have with regard to various linguistic forms:

Language acts as an expression of a speaker's attitudes and his influence on the attitudes and behavior of the hearer, and serves as a means for conveying- the speaker's relationship with his interlocutor(s), and for expressing social roles including communication roles such as questioner and respondent. (House, 1997, p. 35)

For achieving an optimal quality of a translation, there should be a match between the ideational and interpersonal functions. Based on the analysis of the source and target texts, no considerable match between the functions was observed.

The covertly erroneous errors which were discovered through the in-depth analysis of the text profiles were enormous. In the register analysis, we found out that the tenor of the original was distorted in many cases especially in the subcategories of social role relationship and social attitude. Some mismatches were found in the subcategories of the lexical and textual means. It should be mentioned that at the level of language/text, according to Table 4, there was a relative match between the source and target texts.

Moreover, the overtly erroneous errors were immense particularly in the mismatches of denotative meanings of ST and TT elements. The findings of the study illuminated that the translation was neither an overt nor an adequate but largely a covert and inadequate translation. In other words, the translation was a less overt and less adequate one whereas it should have been an overt translation. Hence, by such errors made in the translation the social effect the target text's readership achieves would be unlike that of the source text's readership. This means that such cases of huge ideological manipulation lead to different and in some cases to contrary social effects. That is, the function of original discourse world is not accessible to the target readership. Thus the translation's readership cannot afford to (a) eavesdrop at a lingua-cultural distance and (b) appreciate the original textual function and (c) observe and/or judge the translation from outside. On the other hand, an overt translation is equivalent at the levels of text, register, and genre. On the contrary, the register of the translation text in this paper was heavily distorted in some cases and a relative distortion at the level of text/language was obvious. This indicates that co-activating the source text discourse world did not occur properly in its best possible proportion.

Finally, it can be claimed that since the translation is not significantly equivalent at the levels of text, register, and genre, it is cannot be considered as an overt translation. Therefore, the translation was not successful in co-activating the source text discourse world. Furthermore, the transmutation and deception of the original permeated the translation. Thus, linguistically and psycholinguisticly, it can be considered not as a hybrid entity and an overt translation but as a homogeneous entity and a covert translation.

For House (1997, 2009), the priority of the translation criticism is in the following order: (a) linguistic-text analysis and comparison as the primary concern for providing grounds for arguing an evaluative judgment, (b) considerations of social factors as the secondary but considerable concern. House (2009, p. 56) claims that "linguistic description and explanation should not be confused with evaluative assertions made solely on the basis of social, political, ethical or individual grounds". Judgments of the quality of a translation and the choice of an overt or a covert translation depend "not on the text alone, or on the translator's subjective interpretation of the text," but also on "social factors which concern human agents as well as socio-cultural, political or ideological constraints and which-in the reality of translation practice - turn out to be often more influential than linguistic considerations or the professional competence of the translator [himself or] herself" (House, 2001, p. 254). However, to the best of our knowledge, it is observed that most researches in this realm disregard the second aspect of translation criticism, namely social factors, external influences and communicative effectiveness. Thus this aspect of discourse should be taken into considerable account as well.

However, some of Orwell's novels have been influenced by the current sociopolitical events and novels. Some of his novels and other works, Animal Farm in particular, on the other hand, have been adapted to films, plays and even radio programs up to present (Gradesaver. Retrieved 22/7/2013). According to this website, Orwell's Animal Farm has been adapted to film twice, with a third 3D-version to potentially follow and be directed by Andy Serkis in 2012. Therefore, it is suggested that this adaptation process be investigated meticulously.

Regarding recent innovations in translation studies and specifically in the realm of translation, Baker (2010, p. 1) claims that "translation studies has come of age". She continues:

Human behavior is too complex and too dynamic to be streamlined into stable sets of choices that can be tied to specific textual or non-textual features. We can now engage with innovative new research that is not 
necessarily indebted to the theories with which we are most familiar. We can afford to think outside the box. . . . [Therefore, there should be a move towards approaches that are] deliberately prospective rather than retrospective in orientation ... [in order to] explore new ground, rather than pay tribute to and consolidate past achievements.

\section{Acknowledgment}

I acknowledge the indispensable contribution, encouragement and inspiration of my professors, especially Dr. Salmani and Dr. Haji Boland whose meticulous reading of the first draft and very constructive comments gave me a real insight into the study. Moreover, acknowledgements and appreciation are due to Prof. Juliane House from the University of Hamburg, Germany, whose online suggestions and recommendations have shed significant light into this study. Finally, I thank my wife, Fatemeh, for being patient and extremely helpful during my studies.

\section{References}

Baker, M. (2010). Critical Readings in Translation Studies. UK: Routledge.

Chilton, P., \& Schäffner, C. (1997). Discourse and Politics. In T. A. Dijk, Discourse as Social Interaction (pp. 206230). London: Sage Publications.

Gagnon, C. (2010). Political Translation. (Y. Gambier, \& L. Van Doorslaer, Eds.) Handbook of Translation Studies, 1, pp. 252-256.

Geoffrey, N. L. (1983). Principles of Pragmatics. London and New York: Longman.

Gradesaver Editors (Ed.). (2013). Animal Farm Study Guide \& Literature Essays. Retrieved 7 27, 2013, from http://www.gradesaver.com/animal-farm/.

Guliyev, V., \& Rahim Zadeh Faraji, A. (2010). Heyvanlar Galasi (Heyvanestan). Tabriz, Iran: Tabriz Publisher.

Halliday, M.A.K. (1978). Language as Social Semiotic: the Social Interpretation of Language and Meaning. London: Arnold.

Halliday, M.A.K., \& Martin, J.R. (1993/1996/2005). Writing Science: Literacy and Discursive Power. UK, USA: The Falmer Press.

Halliday, M.A.K., \& Webster, J. (Eds.). (2009). Continuum Companion to Systemic Functional Linguistics. UK, USA and Australia: Bloomsbury Linguistics (formerly Continuum Linguistics).

Hassan, B.-E. (2011). Literary Translation: Aspects of Pragmatic Meaning. Newcastle: Cambridge Scholars.

House, J. (1977). A Model for Translation Quality Assessment. Germany: Gunter Narr Verlag Tubingen.

House, J. (1981). A Model for Translation Quality Assessment. Germany: Gunter Narr Verlag Tubingen.

House, J. (1997). Translation Quality Assessment: A Model Revisited. Germany: Gunter Narr Verlag Tubingen.

House, J. (2001). Translation Quality Assessment: Linguistic Description versus Social Evaluation. Meta: Translators' Journal, 46, 243-257.

House, J. (2009). Translation. UK: Oxford University Press.

House, J. (2010). Overt and Covert Translation. (Gambier, Y., \& Van Doorslaer, L., Eds.) Handbook of Translation Studies, 1, pp. 245-246.

Khorsand, M., \& Salmani, B. (2014, March). Anthems as Propaganda: A Discoursal Translation Quality Assessment. International Journal of Language Learning and Applied Linguistics World (IJLLALW), 5 (3), 222-237. Retrieved from http://www.ijllalw.org/finalversion5319.pdf

Martin, J.R. (1993). A Contextual Theory of Language. In B. C. eds., The Powers of Literacy. A Genre Approach to Teaching Writing (pp. 116-136). London: Palmer.

Martin, J.R. (2009). Genre and language learning: A social semiotic perspective. Linguistics and Education, 20(1), 1021.

Mayr, A. (2008). Language and Power: An Introduction to Institutional Discourse. London and New York: Continuum International Publishing Group.

Merriam-Webster. (2014). Retrieved from Merriam-Webster's Collegiate Dictionary: http://www.merriamwebster.com/dictionary/

Munday, J. (2008). Introducing Translation Studies: Theories and Applications (2nd ed.). UK: Routledge.

Newmayer, F. (1980). Linguistic Theory in American. New York: Academic Press.

Orujovun, A., et al (Ed.). (2006). Azerbaijani Language Explanatory Dictionary. Baku, Azerbaijan: Azerbaijan Academy of National Sciences. 
Orwell, G. (1945/1976). George Orwell: Animal Farm, Burmese Days, A Clergyman's Daughter, Coming Up for Air, Keep the Aspidistra Flying, Nineteen Eighty-Four: Complete \& Unabridged. Great Britain: Secker and Warburg : Octopus Books.

Oxford University Press (OUP) . (2014). Oxford Advanced Learner's Dictionaries. (Author) Retrieved from http://www.oxfordlearnersdictionaries.com/

Richards, J. C., \& Schmidt, R. W. (2002). Longman Dictionary of Language Teaching and Applied Linguistics (3rd ed.). UK: Longman.

Schiffrin, D. (1994). Approaches to Discourse. London: Blackwell.

Smiley, J. (2005). Thirteen Ways of Looking at the Novel. New York: Knopf.

SparkNotes Editors (Ed.). (2007). SparkNote on Animal Farm. Retrieved 12 13, 2012, from SparkNote: http://www.sparknotes.com/lit/animalfarm/

\section{Appendix}

For the special ideological significance of the original and translation of Squealer's speech in Animal Farm, the original (Orwell, 1945, pp. 33-34) and its Azarbaijani Turkish translation (Guliyev \& Rahim Zadeh Faraji, 2010, p. 42) appeared in this section respectively. It should be underlined that the whole speech and its translation's IPA-transcription, transliteration and back-translation appeared, compared and analyzed sentence by sentence in section 4, data analysis.

"Comrades!" he cried. "You do not imagine, I hope, that we pigs are doing this in a spirit of selfishness and privilege? Many of us actually dislike milk and apples. I dislike them myself. Our sole object in taking these things is to preserve our health. Milk and apples (this has been proved by Science, comrades) contain substances absolutely necessary to the well-being of a pig. We pigs are brainworkers. The whole management and organization of this farm depend on us. Day and night we are watching over your welfare. It is for your sake that we drink that milk and eat those apples. Do you know what would happen if we pigs failed in our duty? Jones would come back! Yes, Jones would come back! Surely, comrades," cried Squealer almost pleadingly, skipping from side to side and whisking his tail, "surely there is no one among you who wants to see Jones come back?"

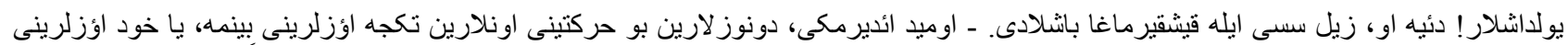

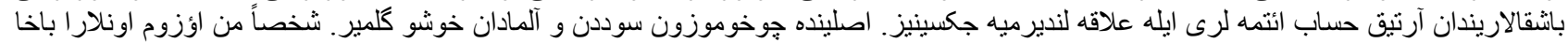

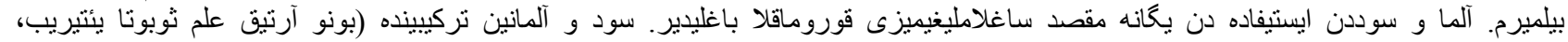

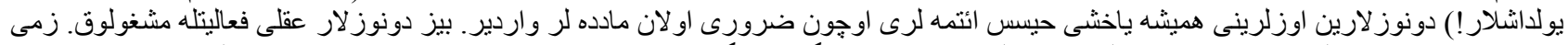

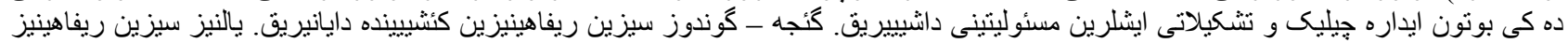

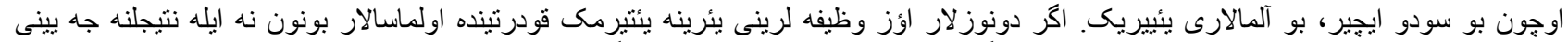

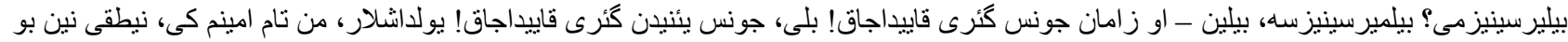

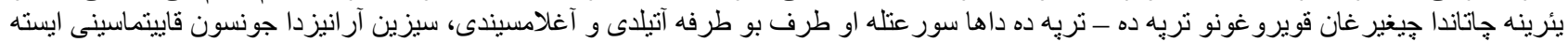

